\title{
Fanconi Anemia Group F Protein
}

National Cancer Institute

\section{Source}

National Cancer Institute. Fanconi Anemia Group F Protein. NCI Thesaurus. Code C85891.

Fanconi anemia group F protein ( $374 \mathrm{aa}, \sim 42 \mathrm{kDa}$ ) is encoded by the human FANCF gene.

This protein may play a role in both cell cycle checkpoint regulation and DNA damage repair. 